\title{
Application Model Cooperative Integrated Reading and Composition (CIRC) to Improve Reading Comprehension Skills of Class V Elementary School Student
}

\begin{abstract}
Sofia Nur Azhari ${ }^{1}$, Isah cahyani ${ }^{2}$, Putri Kirana ${ }^{3}$
Universitas Pendidikan Indonesia

Sofianurazhari@upi.edu ,isahcahyani@upi.edu,putrikirana@student.upi.edu

Abstract: research was motivated by the low skills of students reading comprehension main focus on subjects Indonesian. Students are still not able to control aspects of reading would like to understand the content of reading, determining the main idea or infer the content of reading. The study was conducted in class V SDN Cibukamanah Cibatu District of Purwakarta. There are 28 students involved in the study, which consisted of 13 male students and 15 female students. The method used in this research is the Classroom Action Research (CAR), which consists of four phases: planning, implementation, observation and reflection and is done in two cycles. Data were collected through observation and preliminary tests. Seen from the initial test results showed that the students only scored an average of 59.82 with a percentage of $59.82 \%$ are less and does not reach the predetermined value $\mathrm{KKM}$ is 63. To overcome these problems, researchers applied learning models Cooperative Integrated Reading Composition (CIRC). The purpose of this study was to determine the activity and student learning outcomes in reading comprehension skills, after applying the model of Cooperative Integrated Reading And Composition.The findings of the research results can be seen from the acquisition percentage mastery learning achievement of students overall from starting the first cycle which scored an average of 70.8 with a percentage of $70.71 \%$ in the category quite well. Then increased in the second cycle the average value obtained at 75.89 with the percentage of $75.89 \%$ uncategorized well. From these results, it can be concluded that the application of the model Cooperative Integrated Reading And Composition (CIRC) can improve student learning outcomes, especially reading skills of understanding that seen at the end of each lesson the first cycle and the second cycle showed a considerable increase in value and target indicators in addition to improving learning outcomes also increase the activity of students during the learning process in class V SDN Cibukamanah.
\end{abstract}

Keywords: model Cooperative Integrated Reading And Composition,reading comprehension skills

\section{Introduction}

Education in primary school is an institution that is managed and regulated by the government engaged in organized formal education and lasts for 6 years from grade 1 to grade 6 . In doing so, education in primary schools is given to students with a number of materials or subjects that must be mastered. One of the subjects that students must master is the Indonesian subjects. 
Learning Indonesian important for students to learn in school, because remember that the function of language as a communication tool, the learning Indonesian trying to acquire the skills to communicate both orally and in writing. It is seen that the Indonesian language learning is about the efforts to obtain a series of language skills. Tarin (2008, p.1) suggests that language skill has four components: (1) listening skills; (2) speaking skills; (3) reading skills, and (4) writing skills .Each skill was so intimately associated with the three other skills in a way that diverse.

Skills to read is one of language skills are very important, because these skills have many functions in human life, even that reading is one of the main factors in determining the success of one's academic, As we know that most of the knowledge presented in the form of written language that requires children to do reading activities in order to gain knowledge.

When we begin to read, we actually have a number of initial decisions to make, and we usually make these decisions very quickly, almost unconsciously in most cases. Most of people read for general comprehension. Here we might read a novel, short story, a newspaper article or a report of some type to understand the information in the text, to be entertained and to use the information for a particular purpose, Cadlin and Hall (2002:13) states that there are seven purposes of reading.

According to Heilman $(1981 ; 265)$ reading is a process of making sense of written ideas through meaningful interpretation interaction with language. A good reader is one who understands what he reads, and the faster he able to get meaning from his reading the more efficient he is.

Rahim (2008, p.1) explains that the learning process is most effectively done through reading. People who love to read will gain new knowledge and insights that can improve intelligence so that they are better able to meet the challenges of the future. Read more and more important in people's lives are complex because every aspect of life involves reading. Although information can be found through other models such as audio-visual models, but the role of reading can not be replaced in its entirety. Therefore, reading skills should get more attention, especially when the students are in elementary school, so that students' reading skill can thrive in the future.

Learning to read in elementary school has an important role in learning Indonesian. Through learning to read, the teacher can develop moral values, reasoning ability, and creativity of the students this opinion expressed by Akhadiah (Darmiyati Zuhdi and Budiasih, 2001, p.56). Reading skills are always present in every theme of learning. This shows the importance of mastering the skills of reading, because reading skills is one of the standard literary language skills and Indonesia that must be achieved in education, including at primary school level. Reading skills become the main base not only for teaching the language itself, but for also teaching other subjects.

The ultimate goal of reading is to understand the content of reading, but the fact that there are not all students can achieve these goals. Many children who can read fluently a reading material but do not understand the contents of the reading materials. Reading comprehension is one aspect of language skills that must be mastered by elementary school students, especially in the advanced class. Through these activities, students can 
obtain information actively receptive. Called receptive because by reading, one would obtain information, acquire knowledge and new experiences (Darmiyati Zuchdi and Budiasih, 2001, p.56).

The selection of learning materials becomes an important component, this is as stated by Montero, et al. (2014) in his research that the teaching of early reading focused on the use of guided reading with directed information text. By using these texts with students in a supportive literacy teaching environment, student intellect is stimulated, their background knowledge is activated, they acquire specific vocabulary, and learn to become more strategic readers

Based on preliminary tests conducted on 26 April 2016 note that the reading comprehension skills of students of class V SDN is still low Cibukamanah be said to be low because the value obtained by the students in aspects of reading comprehension mostly below minimum completeness criteria (KKM). When the test in progress can be seen when students are given questions about the content of reading material being read, students can not answer quickly, and should reopen the reading material he read them.

Vocational students' reading comprehension class V SDN Cibukamanah needs to be improv ed by implementing new models of learning and different from previous learning, so that students' reading comprehension skills can be increased, thus helping them in other subjects. Reading skills are not only used in Indonesian subjects alone but all subjects. Sari (2014: 647) before starting learning the teacher prepares lesson plans that are made classically, then prepares usable media that are available at school.

According to this problem, to solve the problem of learning in reading comprehension define an action as an effort to improve the skills of reading comprehension in class V, which is applying the learning model Cooperative Integrated Reading And Composition ( CIRC).

Cooperative Integrated Reading And Cpmposition (CIRC) is one type of learning from models Cooperative learning (CL). In the process of learning to apply this model the students were divided into groups of heterogeneous, does not discriminate between levels of achievement, value or other distinguishing aspects. According to Slavin, the main purpose of the CIRC in particular using a cooperative team is to help students learn reading comprehension for a broad class of high-grade elementary school. Students work in cooperative learning team identified five main aspects of narratives, ie characterization, setting, problem, efforts to solve the problem, end of problem solving (Rahim, 2008, p.35).

In a language learning activity, students create and explaining predictions about how the problems can be solved and summarize the main elements of a story to the other elements of the story. Both of these activities are intended to improve students' reading comprehension skills (Rahim, 2008, p.35).

Cooperative learning is a broader concept covering all types of group work, including forms for more led by teachers or directed by the teacher. Model CIRC learning can be maximized with the direction of teachers, each group will be directed learning to read at the same time understand the contents of reading teachers serve. Each member of the group was divided sections or paragraphs which would be read by 
each of them, and understand the contents of these paragraphs which later information obtained from each member of the group used to answer all the questions or the questions given by the teacher.

Based on the above background, then the issue will be examined in this study expressed generally by the following formula:

1. How the learning activities of students in class V SDN Cibukamanah in learning reading comprehension by applying the model CIRC(CooperativeIntegrated Reading andComposition)?

2. How the results of students of class V SDN Cibukamanah in reading comprehension after applying the model CIRC(CooperativeIntegrated Reading and Composition)?

The study was conducted in an effort to overcome the difficulties of students in reading comprehension. while increasing perestasi students of class V SDN Cibukamanah on learning Indonesian. In particular the objectives of this research are:

1. To investigate the activity of students of class V SDN Cibukamanah during the learning process of reading comprehension by applying the model CIRC(CooperativeIntegrated Reading andComposition).

2. To know the results of students of class V SDN Cibukamanah in reading comprehension by applying the model CIRC(CooperativeIntegrated Reading and Composition).

Someone in conducting an activity, certainly has a specific purpose to be achieved, as well as in reading comprehension. The purpose of reading comprehension is to gain success in the full understanding of the arguments are logical sequences of rhetorical or patterns of text, patterns symbolic, overtones that are emotional and also the means of linguistics used to achieve goals (Tarigan, 2008, p.36). Anderson (Somadayo, 2011, p.12) states that

Reading comprehension has the purpose to understand the content of reading in the text. Objectives include:

1. To obtain details and facts

2. Get the main idea

3. Getting sequence of text organization

4. Getting conclusions

5. Getting classification

6. Making comparisons or disagreement

As a treatment to improve the skills of reading comprehension in learning Indonesian, researchers applied a model of Cooperative Integrated Reading And Composition (CIRC).

\section{Method}

This research was conducted in the academic year 2015/2016 SDN Cibukamanah located at Kampung Pangkalan 2, RT 03 / RW 01 Cibukamanah Village, District Cibatu. The subject of this study that students of class $\mathrm{V}$ with the number of male 
students as many as 13 people and the number of female students as many as 15 people so the total students of class $\mathrm{V}$ is 28 people.

This research applies methods Classroom Action Research (PTK), by applying the PTK is expected to improve and enhance the quality of the learning process, so that their lessons more meaningful.

Qualitative research is a type of formative research. This research uses an ethnographic approach which is basically a very broad field with very large variations of practitioners and methods. Ethnographic approach in general is the observation of participating as part of field research (Moleong, 2016: 26).

This study is an attempt to assess what is happening, what is produced and what is not completed in previous learning. Results reflectors are used to take further steps in order to achieve results in accordance with the purpose of research. That goal can be achieved by performing various alternative actions in solving various problems of learning. Therefore, the focus of the research lies in the class action alternative actions planned by educators, then tested and then evaluated whether-whether such action can be used to solve learning problems being faced by educators or not.

The study design used is classroom action research Kemmis and Mc Taggart carried out by 2 cycles consist of planning, action implementation, observation and reflection. In this study using research instruments in the form of a test reading comprehension evaluation and observation sheet consisting of observation sheet aktivita student and teacher activity observation sheet.

As for the collection of data used in this research is data collection techniques by sorting data sources, data types, and the instrument is used. Data relating to student learning outcomes in reading comprehension skills are collected through tests. Data relating to the activities of students and teachers gathered with observation. As well as data for evidence that learning has been implemented collected by documentation in the form of photographs.

Data has been collected in the form of observations, document portfolios son, document images and video recording will not be meaningful without analyzed are processed and interpreted. Analysis of the data is basically aimed at quantitative and qualitative information to process such a way that it becomes meaningful information (Pardjono, et al, 2007, p.53).

Quantitative data is information that appears in the field and has characteristics that can be displayed in numeric form. While the qualitative data is all the information obtained from the data sources, such as interviews, observation, syllabus, curriculum, teaching models and examples of student work (Pardjono, et al, 2007, p.54). Can be seen the achievement of research goals is to see an increase in the average score obtained from the test reading comprehension. After all the data is collected the next step is to process and analyze the data. The data in this study is the student activity observation data and test data of students in learning.
A. Observations
1) Activities Students
$=\underline{\text { Sum of scores obtained }} \times 100 \%$ 
Total maximum score

2) The percentage of the average value of student activity (\%)

$=$ the average value $\mathrm{x} 100 \%$

3) Fitness Guru

= $\underline{\text { sum of scores obtained }} \times 100 \%$

Total maximum score

b. Test results

1) Scoring

Scoring given to each student and the answer given after each item is completed the scoring on the next take the average value. Each of the questions that can be answered by the students will be scored according to the assessment criteria.

As for how to calculate the results (scores) obtained by the formula mean or average value (Arikunto 2010, p.284-285) as follows

$\mathrm{X}=\mathrm{x} 100$

Description:

$\mathrm{X}=$ mean (average)

$\Sigma \mathrm{x}=$ Number of correct answers

$\mathrm{N}=$ the total score of

2) Determine the percentage of mastery learning

As for how to calculate the complete learn student that is, if $>85 \%$ of students obtain $>63 \%$ of the total score, then learning can be said to be successful. The formulation used

is: $\% \mathrm{KKM}=\underline{\mathrm{KKM} \geq .100 \%}$

Description:\%

$\mathrm{KKM}=$ presenstasi mastery learning

$\geq \mathrm{KKM}=$ number of students whose value is equal to or more than KKM (63)

$=$ Number of students

3) Interpreting the Data

Interpretation of research data obtained from all data from beginning to end activities. This interpretation is intended to gain an overview and generalizations about the effectiveness of the implementation of the model Cooperative Integrated Reading And Composition in improving reading comprehension, interpretation of test data results the ability to read either before or after using model CIRC uses a scale percentage of answers that students using a five-point scale.

Table 1. Percentage Rate Mastery

\begin{tabular}{cll}
\hline No. & \multicolumn{1}{c}{$\begin{array}{c}\text { Percentage interval Mastery } \\
\text { Level }\end{array}$} & $\begin{array}{c}\text { Descript } \\
\text { ion }\end{array}$ \\
\hline 1 & $85 \%-100 \%$ & Good all \\
2 & $75 \%-84 \%$ & Good \\
3 & $60 \%-74 \%$ & Quite \\
\hline
\end{tabular}




\begin{tabular}{ccc}
\hline 4 & $40 \%-59 \%$ & $\begin{array}{c}\text { Less } \\
\text { than }\end{array}$ \\
5 & $0 \%-39 \%$ & Fail
\end{tabular}

SDN Cibukamanah set of classical learning completeness percentage is considered successful if the number of students who scored $\geq 63$ (KKM) the achievement of a minimum of $85 \%$ of the number of students.

\section{RESULTS AND DISCUSSION}

\section{A. RESULTS}

From the preliminary data have been obtained and then analyzed, we then carried out remedial action in terms of improving skills of reading comprehension, and therefore the researchers are planning a classroom action research that will be done 2 cycles each cycle consisting of one meeting. Includes four stages namely planning, implementation, observation, and reflection. The material presented on folklore or myth that is supported media image. So that students do not feel bored quickly. Every action performed on each cycle, the researchers describe, analyze, and reflect in accordance with the acquisition of the data of each cycle. This is done in order to assess the success of Indonesian language learning, especially reading comprehension skills by applying the model of Cooperative Integrated Reading And compositon (CIRC). The details of each cycle is as follows:

\section{CYCLE I}

The initial step before carrying out the first cycle of the researchers first create a lesson plan (RPP) by applying the model of Cooperative Integrated Reading And Composition (CIRC) subject to be studied with regard to the main idea in a paragraph, and then create a research instrument in the form of worksheets group (LKK) and individual evaluation sheets contained 10 items.

At the core activities of the learning process begins with a series of activities that must be carried out within the group. Before conducting a group of teachers with students perform frequently asked questions about the experience of reading, then the teacher goes on to give an explanation of the concept of reading comprehension and understanding of the main idea in a paragraph. After the explanation given, the teacher then guide students to form a heterogeneous group, here the teacher role in the formation of groups that remain conducive learning environment, students do not fuss form groups according to their own desires. Then each group has been formed receive a text reading entitled "The Origin of Sago Palm Tree and Tree" and also worksheets shared by teachers' groups. In the group, each member of each reading to each other to establish communication with text reading, when one member read the text reading, other members noticed at once noted the important things what is in each paragraph. After the reading process is complete, the students undertake discussions to resolve the questions that have been assigned by the teacher. First, students look for words that are considered difficult and they did not know the meaning. Second, students identify the character of the existing characters in the story and then determine what issues are in 
which students read the story. Third, students write the key points contained in the concluding story or retell the story using their own words "Origin of the palm tree and the tree Sago". Do not forget when the learning process, especially when the student megerjakan matter, the teacher becomes a facilitator to respond to any questions the students. After completion questions answered by the students, with the guidance of teachers elected representatives of the group was asked to come forward to read his work. Done selected groups read their work, other groups provide feedback discussion results were read in class before .. Teachers give rewards to groups that come forward because of the courage and activeness. Before distributing the evaluation sheet reading comprehension, teachers motivate other students to actively participate when the learning process. The teacher shared reading comprehension evaluation sheets for each student, the students are asked to do without collaborating with the group that earlier.

In learning activities that have been carried out in accordance with the planning, the researchers found some of the findings. The findings include:

1. Students are not familiar with the stage-Tahaan lessons. Teachers should pay more attention step by step from each study by using a model CIRC. Master designed the study to be more interesting again for example by setting up permaian to mnegkonidisikan and attract the attention of students.

2. In order for the discussions in the working group Worksheet (EHS) running in a conducive and optimal and is not dominated by a minority of students. So teachers more ways to initiate discussion around to each group discussion and ask what there are still things that have not been understood.

3. For students who still do not dare ask / answer a teacher's question on his own, the teacher gives students the chance to be more active in learning. Each instruction is submitted by teachers must be clarified again.

4. In the use of text do not be too long and the difficulty level of questions also must be considered.

Such findings should certainly be corrected in future learning in the second cycle. The results of the evaluation tests students' reading comprehension skills of class $\mathrm{V}$ average value obtained and perentase obtained categorized quite good, but still have to be continued on the next cycle to achieve learning objectives.

\section{CYCLE II}

In the second cycle researchers have recast the lesson plan to apply the model of Cooperative Integrated Reading And Composition (CIRC) and then prepare two texts that will be used in the learning process and not to forget the media images of the characters of the people in order to make students interested to participate in learning, The learning process continued with a series of activities that must be carried out within the group. Before conducting a group of teachers with students perform frequently asked questions about the experience of reading, then the teacher goes on to give an explanation of the concept of reading comprehension and understanding of the main idea in a paragraph. After the explanation given, the teacher then guide students to form a heterogeneous group, while the same group as the previous meeting. Then each group has been formed receive a text reading titled "Wise King" and also worksheets shared 
by teachers' groups. In the group, each member of each reading to each other to establish communication with text reading, when one member read the text reading, other members noticed at once noted the important things what is in each paragraph. After the reading process is complete, the students undertake discussions to resolve the questions that have been assigned by the teacher. First, students look for words that are considered difficult and they did not know the meaning. Second, students identify the character of the existing characters in the story and then determine what issues are in which students read the story. Third, students write the key points contained in the concluding story or retell the story using their own words "King of Wisdom". Do not forget when the learning process, especially when the student megerjakan matter, the teacher becomes a facilitator to respond to any questions the students. After completion questions answered by the students, with the guidance of teachers elected representatives of the group was asked to come forward to read his work. Done selected groups read their work, other groups provide feedback discussion results were read in class before .. Teachers give rewards to groups that come forward because of the courage and activeness. Before distributing the evaluation sheet reading comprehension, teachers motivate other students to actively participate when the learning process. The teacher shared reading comprehension evaluation sheets for each student, the students are asked to do without collaborating with the group that earlier.

Based on observations in the learning process of the second cycle in mind that application of the model Cooperative Integrated Reading And Composition in particular dengsn Indonesian lessons focus on reading comprehension has shown optimal results. Overall shortage in the first cycle can be repaired on learning in the second cycle, and increased student learning outcomes and activities. Seen a significant improvement from the first cycle and II. Then the action research was stopped on the second cycle.

\section{B. DISCUSSION}

\subsection{Activities Students}

From the observation during the process of learning the Indonesian language in class V SDN Cibukamanah, by applying the model of Cooperative Integrated Reading And Composition with a focus on reading comprehension skills. Actions carried out in stages starting from the first cycle to the second cycle showed activity better student learning. In the first cycle, the student activity is quite good with a percentage of $57.68 \%$. This is due to the majority of students still not quite understand the model Cooperative Integrated Reading AndComposition.In addition, students are still embarrassed to ask, answer questions, and express their opinions, and quite good in listening to the material presented teachers.

The improvements made in the second cycle by providing a stimulus to show images associated with folklore, as well as repeat and merefreksi model of Cooperative Integrated Reading and Composition in order to further optimize the students' understanding of the application of the modelCIRC. in addition, students are guided in a more approachable and more in the works about. As the opinion of Slavin (2008, p. 12) argued that "learning to be successfully absorbed if done with appropriate guidance 
between knowledge with new information". With the application of Cooperative Integrated Reading And Composition information or an existing idea and obtained can be organized systematically. The application of the model Cooperative Integrated Reading And Composition on reading comprehension skills activities make students learn to socialize, work together and respect the opinion of friends.

Good communication between group members began intertwined so that learning is done more fun. Improvements were made in the second cycle, making the student activity quite well with the percentage of $73.93 \%$.

The following table is presented the analysis of the observation of learning activities of students from the first cycle to the second cycle:

Table 4.13 Summary of Results Activities Students from Cycle I to Cycle II

\begin{tabular}{ccc} 
cycle & Percentage & Category \\
\hline I & $57.68 \%$ & C (Good) \\
II & $73.93 \%$ & B (Good)
\end{tabular}

From the table above, can be explained that the value of the activity of students in the first cycle obtain the percentage of $57.68 \% \%$ uncategorized C (Good). Meanwhile, in the second cycle obtain peresentase $73.93 \%$ uncategorized B (Good). Thus, it can be concluded that the application of the model Cooperative Integrated Reading And Composition managed to increase the activity of student learning Indonesian language lessons with a focus on reading comprehension.

Based on observations conducted by the observer / collaborator (teacher class V SDN Cibukamanah), showed the average teacher activity during learning cycle I to cycle II, as follows:

Table 4.14 Summary of Results Activities Teacher of cycle I to cycle II

\begin{tabular}{lll}
\hline Cycle & Average Percentage & \multicolumn{1}{c}{ Category } \\
\hline I & $77.5 \%$ & B (Good) \\
II & $87.5 \%$ & SB (Very Good)
\end{tabular}

Based on the diagram can be assessed that the activities of teachers in the first cycle earn a percentage of $77.5 \%$ is classified B (Good). Meanwhile, in the second cycle obtain a percentage of $87.5 \%$ is classified SB (Very Good). It can be concluded that the activities of teachers has improved and a significant increase.

\subsection{Study Results}

The results of students of class V SDN Cibukamanah in learning Indonesian with the focus of reading comprehension skills before using a model of Cooperative Integrated Reading And Composition is comparatively low, as evidenced by the average value obtained 59.82 students. There are only 13 students (46.43\%), which reached the limit 
due Minimal completeness criteria $(\mathrm{KKM}) \geq 63$, sedangkan15 students $(53.57 \%)$ have not reached the limit completely.

An increase of the activity of student, teacher activity was directly proportional to the results learn the skills of reading comprehension. In the first action model application Cooperative Integrated Reading And Composition on the skills of reading comprehension in cycle I. Acquisition value increase compared to preliminary data, there are 20 students $(71.43 \%)$ reached the limit completely, while the remaining 8 students $(28.57 \%)$ reaching the limit completely.

In the second act, the application of the model Cooperative Integrated reading And Composition on the skills of reading comprehension in the second cycle, the value of student learning outcomes increased again compared with the cycle I. the results obtained are as follows: the average value of 75.89 students, there are 23 students (82.14\%) achieved complete limit, while 5 students $(17.86 \%)$ did not reach the limit completely. Increasing the value of students can occur because the model Cooperative Integrated Reading And Composition allows students to exchange information and learning with other friends. The group was formed in the model of the CIRC are a heterogeneous group, so that within the group there are students who have high ability and low, students with high ability to share and help students who have the ability to lower so that students are less capable encouraged or motivated to learn more.

Here are diagram increase students' test results in reading comprehension skills ranging from initial data pre-cycle, the first cycle to the second cycle

Table 4.15 Summary ofComparison Results Values Study of Early Data, Cycle I, until the Cycle II

\begin{tabular}{|c|c|c|c|c|}
\hline \multirow[t]{2}{*}{ Value } & \multirow[t]{2}{*}{ Complete } & \multicolumn{3}{|l|}{$\begin{array}{l}\text { Initial } \\
\text { Condition }\end{array}$} \\
\hline & & Amount $\%$ & Amount $\%$ & Amount $\%$ \\
\hline$<63$ & $\begin{array}{l}\text { Not } \\
\text { Completed }\end{array}$ & $46.43 \%$ & $71.43 \%$ & \\
\hline$\frac{82.14 \%>}{63}$ & Completed & $53.37 \%$ & $28.57 \%$ & $17.86 \%$ \\
\hline Top Value & & & & $90,100,100$ \\
\hline lowest value & & 45 & 55 & 60 \\
\hline Average test $\mathrm{S}$ & Scores Student & 59.82 & 70.8 & 75.89 \\
\hline $\begin{array}{l}\text { Percentage } \\
\text { Learning (\%) }\end{array}$ & of mastery & 46.42 & 70.71 & 75.89 \\
\hline Category & & Poor & Fair & Good \\
\hline
\end{tabular}




\section{CONCLUSION}

Based on the exposure results showed, it is the conclusion of the research is as follows:

In the first conclusions will be presented regarding the activities of students. During the course of research, activity of students in learning activities by applying the model of Cooperative Integrated Reading And Composition (CIRC). Activities of students have experienced a pretty good improvement of the implementation cycle I with percentage $(57.68 \%)$ is classified quite well up to the implementation of the second cycle reaches a percentage (73.93\%) uncategorized well. It can be concluded that through the application of models Cooperative Integrated Reading And Composition student activity goes well, this can be seen through the results of observational data that states that the percentage of student activity is high.

As for the second part related to increased learning outcomes skills of reading comprehension after menenerapkan models Cooperative Integrated Reading And Composition has increased very significantly. Completeness level learning outcomes (graduation) has increased from the initial data for the first cycle and the cycle I To the second cycle. Based on preliminary data the average value of 59 students, 82 with the percentage of $46.42 \%$ which only looks less good and more than half of the total number of students has not reached the limit of minimum completeness. Then, after applying the model of Cooperative Integrated Reading And Composition for two consecutive cycles, and a series of tests that have been carried out on the implementation of the first cycle of the average value obtained of students increased to 70.8 with a percentage of $70.71 \%$, but not yet can be said to be good, there are still many students who do not meet the maximum value in every aspect of the assessment criteria. Through the implementation of the second cycle corrective action can be seen a significant increase, the student has achieved mastery expected, the average value of students' reading comprehension skills tests reached 75.89 with a percentage of $75.89 \%$. So that conclusions can be drawn by the researchers is that the adoption of the Model Cooperative Integrated Reading And Composition for Improving Reading Comprehension Skills in Elementary School Students (Class Action Research in Class V SDN Cibukamanah Cibatu District of Purwakarta District Academic Year 2015/2016) declared successful.

\section{REFRENCE}

[1] Cadlin, N. Christoper \& Hall, R David. (2002). Teaching and Researching Reading. White Plain :Pearson Education.

[2] Heilman W.Arthur, Blair R.Timothy \& Rupley H.William. (1986). Principles and practices of teaching reading 5th. Ohio: Bell and Howell.

[3] Moleong, L.J. 2016. Metodologi Penelitian Kualitatif Edisi Revisi. Bandung: PT. Remaja Rosdakarya.

[4] Montero, M.K., Newmaster, S., \& Ledger, S. 2014. "Exploring Early Reading 
Instructional Strategies to Advance the Print Literacy Development of Adolescent SLIFE”. Journal of Adolescent \& Adult Literacy, Vol. 58, No. 1, pp. 59-69.

[5] Pardjono, dkk. (2007). Panduan Penelitian Tindakan Kelas. Yogyakarta: Lembaga Penelitian UNY.

[6] Rahim, Farida. (2008). Pengajaran Membaca di Sekolah Dasar. Jakarta: Bumi Aksara.

[7] Sari, D.P. 2014. "Pelaksanaan Pembelajaran Membaca Permulaan Bagi Anak Kesulitan Membaca di MIN Koto Luar Padang (Deskriptif Kualitatif)". EJUPEKhu (Jurnal Ilmiah Pendidikan Khusus), Vol. 3, No. 3, hlm. 644652.

[8] Somadayo, Samsu. (2011). Strategi dan Teknik Pembelajaran Membaca. Yogyakarta: Graha Ilmu.

[9] Tarigan, Guntur, Henry. (2008). Membaca sebagai Suatu Keterampilan Berbahasa. Bandung: Angkasa.

[10] Zuchdi, Darmiyati dan Budiasih. (2001). Pendidikan Bahasa dan Sastra Indonesia di Kelas Rendah. Yogyakarta: PAS. 